DOI: 10.30519/ahtr.941911

Advances in Hospitality and Tourism Research (AHTR)

\title{
EXAMINING THE RELATIONSHIP BETWEEN SUBJECTIVE VITALITY AS A PERSONALITY TRAIT, EXPERIENCE QUALITY, AND ENVIRONMENTAL STEWARDSHIP OF TOURISTS VISITING ATATÜRK ARBORETUM
}

\author{
Mustafa Cevdet ALTUNEL ${ }^{1}$ \\ Department of Tourism Guidance, Krklareli University, Turkey \\ ORCID: 0000-0001-6382-5526
}

Murat YALÇIN

İstanbul Erenköy Training and Research Hospital for Psychiatry and Neurology, University of Health Sciences, Turkey ORCID: 0000-0002-1129-8960

\begin{abstract}
Subjective vitality is usually discussed theoretically in a business context but it has important practical implications as well. This study examines subjective vitality as a trait and personal resource, in the context of outdoor recreation and garden tourism. Visitors of Atatürk Arboretum, Istanbul were surveyed, and a model was proposed and tested to examine the relationship between subjective vitality and experience quality based on conservation of resources theory and environmental stewardship (attitudinal stewardship and behavioral intentions). The results confirm that subjective vitality has a significant and positive effect on experience quality. Further, experience quality has a significant and positive effect on attitudinal stewardship, which, in turn, has the same effect on behavioral intentions. This implies that, after having a good experience, a visitor may feel more connected to the park, more willing to help, and more inclined to revisit and advocate.
\end{abstract}

\author{
Article History \\ Received 24 May 2021 \\ Revised 07 September 2021 \\ Accepted 29 November 2021 \\ Published online 01 Feb. 2022

\section{Keywords} \\ subjective vitality \\ personality trait \\ conservation of resources \\ theory \\ experience quality
}

\section{INTRODUCTION}

Vitality is a widely popular subject and a favorite of science fiction novels. Crake, a brilliant character in Margaret Atwood's utopian novel Oryx and Crake, develops a drug to minimize the harm caused by homo sapiens to themselves and the world. This medicine would provide, among other

${ }^{1}$ Address correspondence to Mustafa Cevdet Altunel (PhD), Tourism Guidance Department, Faculty of Tourism, Kırklareli University, Kayalı Campus, 39100 Center, Kırklareli, Turkey. E-mail: mustafacaltunel@gmail.com 
features, a generalized sense of energy and well-being and prolonged youth. Crake claims that people are helpless against this drug because of the desire for more (Atwood, 2010). In other words, vitality and youthfulness are important in the understanding of such aspects. Sinan Şamil Sam, an intercontinental heavyweight champion, drew attention to this idea in an interview he gave before he died of liver failure in 2015:

After all, human beings are born, live, and die. Boxing is also like this. I would like to be Sinan Şamil Sam in those days when I was popular, to be healthier, more vigorous, more aggressive, and make more money, not a lie, but ... I did it and it is finished (TRT Belgesel, 2015).

Indeed, scholarly reports suggest that "subjective feeling of aliveness and energy" is a significant indicator of personal well-being (Ryan \& Frederick, 1997, pp. 533) and people have general desires/wishes to stay alive and young, reflected in their wish to minimize the effects of aging that diminish health and vitality (Hertzog et al., 2008).

In the literature, many different concepts related to personal energy, such as vigor/activity, liveliness, enthusiasm, zest have been developed (McNair et al., 1971; Ryan \& Frederick, 1997; Thayer, 1987). One of these, subjective vitality (SV), was first considered as a separate title by Ryan and Frederick (1997). According to these researchers, SV is "the energy available to one's self" and defined as "one's conscious experience of possessing energy." (Ryan \& Frederick, 1997, pp. 530-533) The concept refers to the physical and mental energy of a person, and vital people are said to “experience a sense of enthusiasm” (Ryan et al., 2010, pp. 159).

The relationship between SV and many different variables has been investigated in different disciplines. According to organizational behavior literature, businesses prefer that employees have high positive vitality. In one of the non-empirical preliminary studies, Shirom (2007) suggested that physical, emotional, and cognitive vigor have potential effects on life satisfaction, physical and mental health, job satisfaction, job performance, and organizational effectiveness. Dubreuil et al. (2014) pointed out that SV has a significant and positive effect on work performance. Similarly, Carmeli et al. (2009) claimed that vigor has an impact on job performance. Furthermore, Kark and Carmeli (2009) concluded that employees who are lively and energetic in the workplace are more inclined to jobs that require creativity. Porath et al. (2012) determined that thriving, which includes a sense of vitality and learning, affects burnouts negatively; additionally, a positive effect is noticeable on individual job performance, general health, and leadership effectiveness. These studies emphasize that employees with 
high energy levels are more motivated, and have a greater capacity to accomplish their jobs and make significant contributions to the business (Shirom, 2007).

In studies regarding the medical sciences, an emphasis is placed on the importance of SV and relevant human wellbeing concepts. According to Penninx et al. (2000), in disabled older women, emotional vitality has positive effects on their disability and mortality. Likewise, Polk et al. (2005) determined that the trait negative affect is associated with higher concentrations of total cortisol which is main stress hormone of human body. In another study, vitality was reported to be a significant predictor of weight change since lower level of vitality ends up with less weight loss (Swencionis et al., 2013). Finally, Deen et al. (2020) discovered that an increase in emotional vitality resulted in a subsequent decrease in allostatic load.

Some studies have investigated the effect of SV on life satisfaction. Lucas et al. (2019) highlighted that vitality positively and significantly affects four domains of life satisfaction (i.e., psychological and physical health, environment, and social relationship), where they treated vitality as a mediator variable between hope and life satisfaction. Salama-Younes and Hashim (2018) also suggested that vitality positively and significantly affects life satisfaction, and they consider SV as a mediator variable between passion (i.e., harmonious and obsessive) and life satisfaction. Further, Çelik (2017) reports that vitality plays the role of a mediator between proactive personality and life satisfaction, and therefore significantly affects life satisfaction.

Notably, the concept of vitality may answer questions such as "how can I do my job with higher performance and quality", and "how can I live a healthy, high quality, and satisfactory life". People with higher vitality appear to be more successful in various areas of life. Vitality can manifest as a trait -enduring, related to an individual's characteristics- or a state increasing temporarily due to factors such as physical activities/meaning in life- (Ju, 2017), social interactions (Chang \& Kao, 2019), socializing time (Kheiraoui et al., 2012), outdoor experience (Ryan et al., 2010), and mindfulness (Allen \& Kiburz, 2012; Martin-Cuellar et al., 2019).

Individuals' desires for life satisfaction are inextricably linked to their occupations (Erdoğan et al., 2012). Vacations are also attributed great significance as affecting life satisfaction the most (Nawijn \& Veenhoven, 2011). Working life and vacations are two central elements of life (Altunel et al., 2017). Through performance and healthy relationships in workplace, 
a person wants to experience satisfaction in business life. Similarly, considering tourism activities as one of the most common sources of pleasure in daily life, it is understandable for tourists to want to have a good experience during holiday. However, the quality of this experience seems related to the individual characteristics of tourists, as well as the quality of provided services (Altunel \& Koçak, 2017). Thus, this study's primary purpose is to investigate the effect of $\mathrm{SV}$, as an original subject in tourism, on the experience quality of tourists.

Destinations and businesses want to constantly increase the experience and satisfaction of tourists. If the level of vitality affects the quality of experience, it would not be correct to suggest or offer the same services to tourists with both low and high vitality. Therefore, destinations and businesses should be able to use SV as a segmentation criterion.

Accordingly, the study attempts to investigate the relationship between SV, experience quality (EQ), attitudinal stewardship (AS), and behavioral intentions (BI) through a model. Since the vitality level is considered to be imperative, especially in tourism or recreational activities that require a certain level of physical engagement, the data were collected from the visitors of the Atatürk Arboretum. The primary aim of the study is to examine the effect of SV on EQ and the mediation effect of EQ in the relationship between SV and AS. The secondary aim is to investigate the effect of EQ on AS and the effect of AS on BI. Understanding these relationships is valuable in assisting tourism establishments to provide a better quality of experience by delivering services in line with their customer profile. In addition, the theoretical foundation of this relationship has been missing in previous studies investigating the effect of SV on EQ (Altunel \& Koçak, 2017; Su et al., 2020), a gap that this study intends to fill.

\section{LITERATURE REVIEW}

\section{Subjective Vitality}

Vitality is derived from the Latin word vita (i.e., life) and is understood as a dynamic phenomenon that affects both mental and physical components of functioning, such as activity, and so refers to an individual who is alive and energetic (Ryan \& Bernstein, 2004). However, it is known that activity levels vary in mammals and are associated with both genetic and environmental factors. Expression of the motor activity is fundamental for both animals and humans to explore their environment for food and social contact (Kas et al., 2009). 
As in other mammals, energy levels differ among humans. Different individuals exposed to the same stimulus react with varied responses. This variability, influenced by genetic factors, is a personality trait described as temperament (Qiu et al., 2017). Contribution of cultural factors such as degree of modernization, child-rearing practices, maternal orientation, ecological setting, and specific early life events influencing temperament, and the interaction between affective temperaments and cultural dimensions have been previously described (DeVries \& Sameroff, 1984; Gonda et al., 2011). For instance, individuals with hyperthymic temperaments are described as cheerful, overoptimistic, overtalkative, warm, people-seeking, extroverted, and with high energy levels. This state is also considered to be linked with positive emotions and protective against suicidal ideation and behavior (Kobayashi et al., 2019). Additionally, psychological factors in individuals' daily life (i.e., being in love) may affect their vitality and as a result, in certain circumstances or events, make them feel either alive or drained (Ryan \& Frederick, 1997).

Throughout history, the concept of psychic energy has been approached differently in western and eastern civilizations. For example, in the psychoanalytic theory established by Freud, the economy of psychic energy varies depending on how the person invests, but energy can be gained and lost; spending psychic energy to deal with conflict and tension reduces the energy available (Freud, 1962). The eastern tradition mentions unlimited energy that can be reached with the help of Qi (Jou, 1981).

Until recently, the subjective experience was usually neglected in scientific research because the data were only considered scientific if it was reproducible and collected by an external, neutral, and objective observer or experimenter. Despite this basic principle of experimental psychology, the so-called "third-person data", a considerable amount of cognitive science researchers have recently concluded that to study cognition, a researcher can no longer be limited to data that can be observed and recorded from the outside, and that it is essential to pay regard to its subjective qualities as experienced in the internal world (Petitmengin, 2006). Stable personality traits have been confirmed to predispose people to experience moderately stable levels of favorable and adverse life events and also moderately stable levels of subjective wellbeing (Headey \& Wearing, 1989). Individuals with high levels of vitality are inclined to improve, prolong, or re-enact the conditions wherein their vital energies are increased, and to view events positively and patiently (Kark \& Carmeli, 2009). Further, SV affects the effort that people invest in wellbeing-inducive activities and can indicate the positivity of the overall experience (Ryan \& 
Frederick, 1997). Moreover, increased physical activity, supplemented by $\mathrm{SV}$, is an element of enjoyment and directly associated with psychological wellbeing; it is also correlated to better cognitive and intellectual performance (Biddle \& Mutrie, 2007). Consequentially, SV is defined as a dynamic reflection of well-being by Ryan and Frederick (1997) and considered a personality trait that is reported directly by an individual (Lucas et al., 2019). This cardinal characteristic can have significant impacts on the experience of life events and may provide a better understanding of individualized tourism services.

\section{Experience Quality}

In the marketing space, a good-centered view has been substituted by service-dominant philosophy (Vargo \& Lusch, 2004). SERVQUAL and SERVPERF, known as the scales of service-dominant logic, do not fit well with the experience side of services (Fick \& Ritchie, 1991). Therefore, in certain ways, EQ differs from service quality. Otto and Ritchie (1996) assert that in terms of measurement, it is subjective, it has a generalized scope, and its evaluation is not attribute-based but holistic/gestalt. Besides, it is noted to bestow experiential/hedonic/symbolic benefits, and the psychological representation is affective and not cognitive/attitudinal. However, the evaluation of the experience is not just concerned with emotions, although a great emphasis is placed on emotional or affective nature (Chang \& Horng, 2010). Similarly, Gentile et al. (2007) consider that experience is subjective and involvement of the customer's may be at a rational, emotional, sensorial, physical, and/or spiritual level.

Tourism experience is defined as a continuous flow of ideas and feelings during periods of consciousness that emerge as a result of highly complex psychological, sociological, and cognitive interactions (Kang \& Gretzel, 2012). The dimensions of EQ are detailed as hedonic, peace of mind, involvement, and recognition in an early study (Otto \& Ritchie, 1996). In another preliminary study, Pine and Gilmore (1998) offer an EQ scale encompassing four dimensions: entertainment, aesthetic, educational, and escapism. Binkhorst (2007) considers that a sense of escape is essential in the creation of personal experience. Furthermore, Kao et al. (2008) stated that experiential quality composes four dimensions (i.e., immersion, surprise, participation, and fun). Suhartanto et al. (2020) discussed the EQ in terms of learning, peace of mind, involvement, recognition, and escape. Lastly, Kang and Gretzel (2012) conducted a three-dimensional examination of the construct (i.e., enjoyment, learning, and escape). In the present study, we prefer the Kang and Gretzel's (2012) classification 
because it highlights the principal components of the experience in the arboretum. Learning is related to the requirement of information (Pearce, 2005); for example, visitors obtain information about trees. Enjoyment is related to the requirement of fun (Davis et al., 1992); for example, visitors can experience a sense of fun due to the beauty of trees and plants, relevant and interesting stories shared about them, or participation in events organized within the arboretum. Lastly escape is related to the feeling of deviating from the routine (Pearce, 2005), as visitors have the opportunity to get rid of the noise and stress of the city.

\section{Environmental Stewardship: Attitudinal and Behavioral Intentions}

Environmentalism, originated from industrial revelation, encompasses a diverse spectrum of perspectives on the interaction between humans and their natural environment, and the strengthening of the environmental stewardship is related with the expansion in the international environmental agenda (Falkner \& Buzan, 2019). Environmental stewardship relates to being accountable for the earth and can be defined as "a type of resource management; a behavior change; an educational process; or a conservation technique" (Norman, 1999, pp. 34). It entails a commitment to the protection, preservation, and improvement of our natural resources regardless of economic gain (Hancock, 2007). Similarly, Lopez (2020) stated that environmental stewardship refers to individual or communal action directed toward the protection and/or promotion of the environment.

One of the fundamental goals of arboretums and national parks is to contribute to the development of environmental awareness (Atatürk Arboretum Web Site, n.d). For this purpose, they can organize educational programs in cooperation with universities, ministries, other arboretums, and botanical gardens. Through interpretive services and educational programs, visitors can join in volunteering, training, and teaching activities and projects (Department of Conservation of the New Zealand Government, n.d.). Furthermore, through such mechanisms, empathy for environmental protection can be nurtured (Stewart et al., 1998) and ordinary visitors can become active supporters (Kang \& Gretzel, 2012).

Environmental stewardship may be examined in two levels: attitudinal and behavioral stewardship (Stern et al., 2008). Attitudes "refer to the evaluation of a specific object, quality, or behavior" and are derived from and reflect abstract values (Leiserowitz et al., 2006, pp. 414). On the other hand, behavior is a function of attitudes and subjective norms 
(Polonsky et al., 2012). Thus, researchers generally seek to predict the intentions behind the behaviors rather than the behaviors themselves (Ajzen \& Fishbein, 1980).

\section{Hypothesis Development and Conceptual Model}

The study proposes that the preliminary level of visitors' vitality and energy affects the quality of the overall experience. Correspondingly, Martin-Ruiz et al. (2010) considered the concept of effort sacrifice as an element of visitor's evaluation index because one of the criteria that the visitor of an archaeological site will use to evaluate their own experience is the perception of effort involved in the service delivery. The idea of effort sacrifice is central because people have limited energy levels. Visitors will be happy to use their energies to experience the service's core benefit, but many will not want to use their energies to the maximum. Especially, if all of the energy is consumed at the beginning or in the middle of the touristic activity, it will be problematic to enjoy the rest of the day or to have a good experience. Hence, while choosing an activity, visitors will be able to partake and enjoy it according to their energy levels. Although the SV can increase in certain conditions (e.g., being in nature), the quality of the experience is predominantly dependent on a person's initial vitality level. In outdoor recreational activities, such as archaeological or other cultural tourism sites, tourists' energy levels are most likely to influence the quality of the experience (Altunel \& Koçak, 2017).

Conservation of Resources Theory (CoR) contends that individuals seek to protect and sustain the resources valuable for them and instinctively avoid losing those resources, especially in negative events (Hobfoll, 2011). Hobfoll (1998, pp. 80-83) proposes that the basic principles of CoR lead to corollaries and some of them are:

"(i) Those with greater resources are less vulnerable to resource loss and more capable of orchestrating resource gain. Conversely, those with fewer resources are more vulnerable to resource loss and less capable of achieving resource gain. (ii) Those who lack resources are likely to adopt a defensive posture to guard their resources."

It is suggested in this study that these two corollaries are essential to explaining the relationship between SV and EQ. In this context, vigor is one of the resources that has an internal locus (Holmgrenn et al., 2017). In line with CoR, individuals with fewer resources are more deeply affected by the stress of losing their job than individuals with more resources (Holmgrenn 
et al., 2017). Csikszentmihalyi (1990) states that when some information contradicts with the purpose of the person, it disrupts consciousness, and some level of attention (attention is also a type of energy) is spent to eliminate the danger, leaving less attention for other tasks. If the person had invested more in increasing his energy (resources -such as more selfconfidence-), he would be less affected by such barriers (Csikszentmihalyi, 1990). So, we can argue that individuals with less vitality, as a trait, are more vulnerable to various difficulties in life than individuals with more vitality because they have fewer resources at their disposal. They may not be able to focus all their energies on a specific goal during recreational activities, because they ultimately spend a significant part of their psychic energies on internal stimuli and conflicts.

Therefore, it is inevitable that people have less psychic energy to experience and stimulate the outside world. However, to have quality experience, a person needs focus and attention, and that is psychic energy (Csikszentmihalyi, 1990). Therefore, if the individual has limited resources to enrich EQ (vigor and mental energy), they are likely to have lower EQ eventually. Conversely, individuals with more resources will be able to allocate more resources to enrich their EQ. As stated in corollary (i), individuals with more resources are more capable of orchestrating resource gain, which enhances EQ. As Csikszentmihalyi (1990) states vigorous individuals are receptive to new experiences, continue to learn until they die, have deep links and commitments to other people and the environment in which they live, and they take pleasure in whatever they do.

As for defensive posture to guard one's own resources, it is necessary to use various psychic and physical energy resources specific to an activity to get a good experience. For example, while a video game requires more intensive use of cognitive resources such as attention, concentration, and quick decision-making (such as war games), an arboretum requires significant physical energy resources as well as cognitive resources (attention and focus) for a better quality of experience. Since people want to protect their limited resources, individuals with insufficient cognitive resources will use less resources in their video games and similarly, individuals with inadequate physical resources will similarly use less in arboretum activities. Therefore, these individuals are likely to leave the activities with low EQ.

This study examines the three dimensions of EQ: learning, enjoyment, and escape. According to Fini et al. (2010), cheerful and vibrant people are more likely to be fresh and alert. Additionally, Balaguer et al. 
(2018) stated that when youngs feel SV, they have a pleasant feeling, they are active, they have a forward-thinking mentality, and they are eager in developing their talents and opportunities. Besides, energetic people can more easily focus their attention on the task at hand (Ryan \& Frederick, 1997). Furthermore, Tsoi et al. (2018) reveal that SV directly influences lifelong learning. Consequently, it is hypothesized that individuals with high vitality levels can learn exceedingly fast. Individuals with a high vitality level also tend to experience more joy. According to Arkes et al. (1988) individuals who experience high levels of vitality are more likely to see events positively and assume that favorable events will continue to occur. Ryan and Frederick (1997) state that individual efforts invested in the activities are affected by vitality, and vitality can indicate the positivity of their experiences and their personal well-being. Besides, vital people are more active, more resilient to stress, report better mental health (Penninx et al., 2000), and have a desire to feel excitement (Ryan \& Frederick, 1997). Consequently, it is hypothesized that individuals with high vitality levels shall be easily entertained. Brown and Ryan (2004) examined the correlation between the concept of mindfulness, which they measured with presence (i.e., present-centered attention and awareness) and acceptance subfactors, and SV and found a significant relationship between the two. Presence emphasizes the ability of an individual to experience the moment so that they can isolate themselves and find determination by focusing on that moment. Since persons with high vitality can experience a sense of escape by focusing more easily on the moment, it is hypothesized that vitality will affect the likelihood and success of the escape. Altunel and Koçak (2017) and Su et al. (2020) demonstrate that SV positively affects EQ. So it is hypothesized that:

\section{H1: SV positively affects EQ.}

The effects of interpretive services and educational programs organized in national parks or arboretums on environmental stewardship have been widely examined. For example, at the end of the three-day nature-learning trip for schoolkids to Table Mountain National Park, it was determined that environmental interpretive programs had a reasonable effect on pro-environmental attitudes (Ferreira, 2012). Similarly, Wolf et al. (2015) investigated visitor experiences in a special model of thematically connected and guided walking, biking, and four-wheel drive tours in Australian national parks and stated that the experience strengthened participants' attachment to national parks and their sense of environmental stewardship. Halliwell (2019) focused on the concept of "citizen science" in his research and found that there is a shift toward stronger stewardship 
desires following the experience. The citizen science concept is defined as "engagement of non-professionals in the scientific investigation" (MillerRushing et al., 2012, pp. 286). Dopko et al. (2019) found in their experimental study that children who experience 4-hour nature develop a higher attitude towards nature than other children who visit museums. In conclusion, Kang and Gretzel (2012) found that EQ positively affects AS. Hence it is hypothesized that:

H2: EQ positively affects AS.

Several studies suggest that attitudes towards the environment affect environmental behaviors. For instance, studying samples from 27 different countries, Oreg and Katz-Gerro (2006) found that pro-environmental attitudes (i.e., environmental concern and perceived threat) affect proenvironmental behavior (i.e., recycling, refraining from driving, and environmental citizenship). In a study of outdoor recreation activities, Thapa (2010) specified that the participants' attitudes exhibited stronger direct relationships with their behaviors, while Polonsky et al. (2012) claimed that attitude towards the environment has an impact on general and carbon-specific behaviors. Likewise, in their study conducted on adults participating in municipally sponsored volunteer work in Portland, Dresner et al. (2015) validated that environmental identity predicted proenvironmental behaviors. Finally, in Hoover's (2021) study on high school students, it was stated that the environmental attitude significantly affected environmental citizenship behaviors. Hence it is hypothesized that:

H3: AS positively affects BI.

In the existing literature, no scholars have looked into the EQ as a mediator between SV and AS. However, experience is investigated as a mediator in several studies. For example, Altunel and Erkut (2015) found the mediation effect of EQ on involvement and recommendation intention in the cultural tourism context. Additonaly, Su et al. (2020) discovered that authenticity experience (AE) partially mediates the relationship between $\mathrm{SV}$ and EQ, and emphasized that AE increases the impact of SV on EQ. So, we have grounds to suspect that EQ increases the impact of SV on AS. As a result, it is suggested that:

H4: EQ mediates the relationship between SV and AS. 


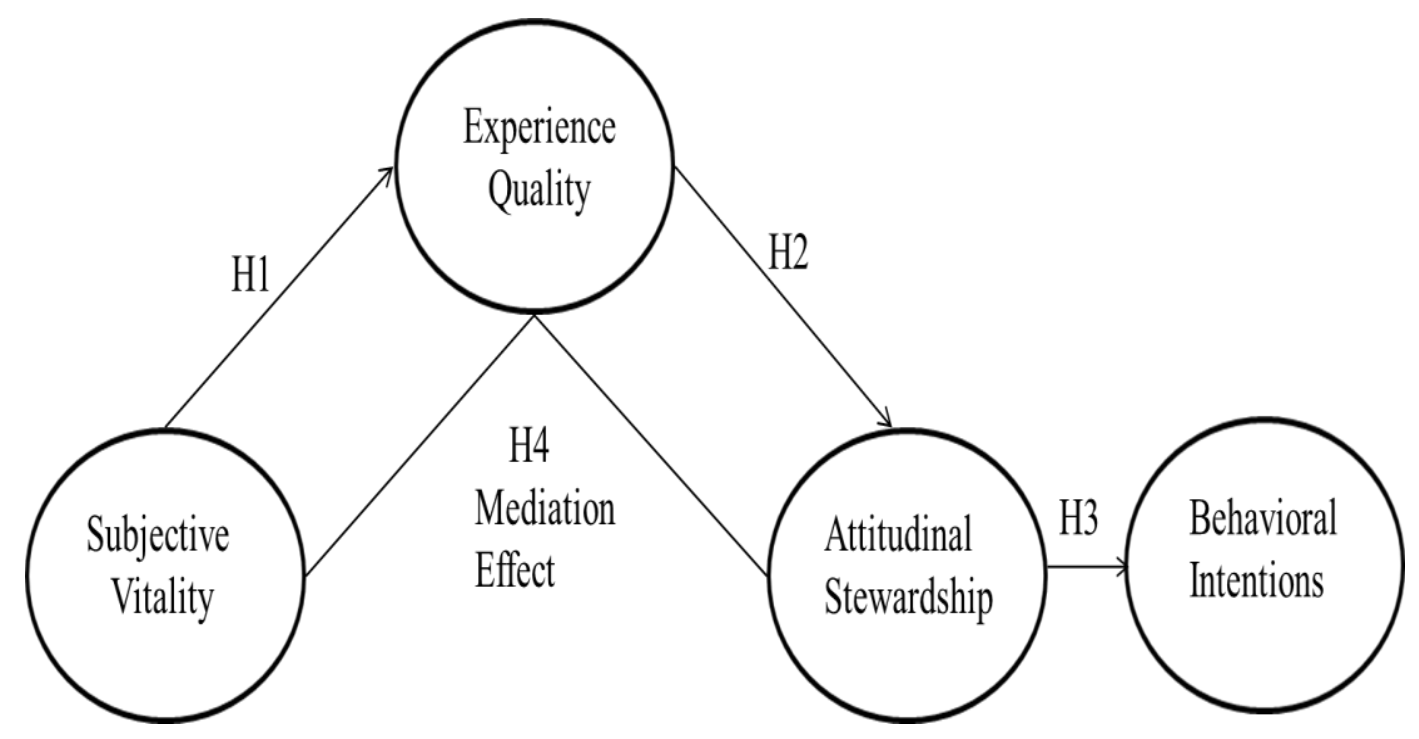

Figure 1. Hypothesized Research Model

\section{METHODS}

This study was conducted on individuals visiting Atatürk Arboretum. Arboretums are part of the public gardens which also include botanical gardens and privately owned gardens open to the public (Ki, 2016). According to the Cambridge Dictionary, an arboretum is a vast garden where a variety of tree species are grown for public enjoyment and scientific study. In tourism literature, arboretum can be observed within the scope of garden tourism or outdoor recreational space but there are few studies on them specifically (Čakovská, 2018; Connell, 2004; Lipovská, 2013).

There are around 1700 botanic gardens and arboretums worldwide (BGCI, 2020), with over six million accessions, and about 80,000 species, thousands of which are endangered in the wild (Chen \& Sun, 2018). As a result, these gardens play an important role in the ex-situ conservation and investigation of regional and worldwide plant biodiversity (Mounce et al., 2017).

According to a global analysis of botanical garden attendance, the United States leads the pack with 80 million visitors each year, followed by Germany with 37 million, the United Kingdom with 31 million, and Canada with 27 million (Benfield, 2013). In 2017, 209.521 individuals visited Istanbul Atatürk Arboretum, compared to 198.300 in 2018 (Ok \& Koç, 2019). Although the exact number of visitors who participate in this sort of tourism in the globe and Turkey is unknown, the number of activities has increased dramatically (Sayılan, 2008). 


\section{Study Area}

Atatürk arboretum covers an area of 296 ha (730 acres) in the southeast of Belgrad Forest, Istanbul. The installation has been used by many institutions with the aim of recreation, scientific research, environmental protection awareness, such as The Faculty of Forestry, Istanbul University, and relevant agencies of the Ministry of Forest and Water Management. Ataturk Arboretum hosts 2000 types of plants from all over the world and can be visited for wedding photography, nature photography, walking, film and advertisement shooting, education, scientific research, leisure time, and bird watching activities (Zeleke, 2018).

\section{Data Collection}

The researchers organized a trip to Atatürk Arboretum to mark a route that respondents would follow. A short route was planned to minimalize the increase in the vitality level of respondents during the tour. Trees positioned close to each other with exciting stories or striking beauty were included in the tour. Five trees, namely Gingko Biloba, Liriodendron tulipfera, Lagerstroemia indica, Liquidambar orientalis, Sequoiadendron giganteum, were selected after careful consideration. Next, the script of trees was prepared. General vegetative information and interesting facts about the trees were provided to participants. For instance, the information about the endurance of Gingko Biloba was explained through the example of trees that were not affected by the nuclear bomb explosion in Hiroshima. Finally, the script was recorded in an audio file.

Immediately after entering the arboretum, the respondents were asked whether they would like to volunteer to answer the questionnaire. The respondents who agreed to participate were introduced to this study, the route, and briefly informed about the trees. Then, they responded to the questionnaire's second section (T1), the SV scale. Subsequently, the researchers sent the audio file to the respondents so that they could listen to the file on their smartphones during the route. After the excursion, respondents completed the rest of the questionnaire (T2). This data collection procedure was repeated for each respondent individually to prevent any possible interaction between the respondents. That is, when one respondent completed all the processes, researchers went to the entrance of the arboretum to find a new respondent and repeat the same procedure. 
The survey was administered by two researchers in Atatürk Arboretum during May and June 2019. 384 questionnaires were collected, and there were no incomplete surveys. About a quarter of those asked whether they would like to participate in the survey stated that they could not participate, often citing time constraints. A convenience sampling method was preferred as random sampling would not suit the present study due to time and financial resource constraints. In this, the respondents were guided through the research process individually and each researcher was responsible for the respondent they discovered until the end of the data collection process

\section{Research Instruments}

The self-administered questionnaire survey consisted of five parts. Part I included questions about demographic information. Part II measured a trait version of the SV scale, with seven items developed by Ryan and Frederick (1997), using a five-point Likert scale ( $1=$ not at all true; $5=$ very true). Part III measured the EQ scale with nine items and Part IV contains seven items about environmental stewardship, namely AS and BI toward stewardship. Part 3 and Part 4 items were derived from a prior research study (Kang \& Gretzel, 2012); a five-point Likert scale was used to measure the constructs ( 1 = totally disagree; $5=$ totally agree). The language of the questionnaire was Turkish.

\section{Data Analysis}

Structural equation modeling (SEM) was used to test the proposed model, to identify the causal relationship among key constructs and one possible mediating effect with the bootstrap method. SEM belongs to a family of statistical models used to simultaneously test and explain the relationships among multiple variables (Hair et al., 2010). IBM SPSS Statistics version 22 and AMOS 22 were used to analyze the collected data.

Originally, as part of the measurement model, 6 latent variables and 24 observed variables were included. The second-order latent construct, EQ, was integrated with latent variables of learning, enjoyment, and escape. They all aggregated to generate one measure of EQ.

Before the model was tested, some preliminary statistical tests were conducted. First, the linearity of the constructs was checked and it was determined whether the relationships are sufficiently linear to be tested through SEM. Second, skewness and kurtosis values were examined to 
check normality. According to Hair et al. (2006), the range outside of -1 to +1 value implies a skewed distribution. Consequently, three items of EQ scale, one item of AS, and one item of BI scale were removed due to the improper skewness values. The remained items had kurtosis values lower than the cut-off value of 3.0. Thereafter, the researchers retained three items with skewness values outside -1 to +1 range $(-1.01,-1.26$ and -1.17$)$ in this study after meticulously deliberating on theoretical justifications and methodological limitations.

\section{RESULTS}

\section{Descriptive Statistics}

The analysis of demographic information denoted that $57.6 \%$ of the respondents were female, $66.9 \%$ of them were single, and $68 \%$ held an undergraduate degree or higher. The mean score of age was 30.4 years, and $64.6 \%$ had a monthly income between 1001-6000 Turkish Liras ( 1 TRY $=0.18$ USD). The respondents spend 2.5 hours on average in their trips and $39 \%$ visited arboretum at least once a year. Table 1 summarizes the sample's demographic characteristics.

Table 1. Demographic Profile of the Sample

\begin{tabular}{lll}
\hline Demographic & Frequency & Percentage \\
\hline Gender & 163 & \\
Male & 221 & 42.4 \\
Female & & 57.6 \\
Marital Status & 127 & 33.1 \\
Married & 257 & 66.9 \\
Single & & \\
Education & 77 & 20.1 \\
High school diploma & 46 & 12 \\
2-year degree & 212 & 55.2 \\
Undergraduate & 49 & 12.8 \\
Postgraduate & & \\
Income & 90 & 23.4 \\
$<1000$ & 120 & 31.3 \\
1001-3000 & 128 & 33.3 \\
3001-6000 & 28 & 7.3 \\
6001-9000 & 18 & 4.7 \\
$>9000$ & &
\end{tabular}


Testing Assumptions of Multivariate Analysis and Common Method Bias

Table 2 presents some of the central tendency/dispersion measures, skewness, and kurtosis values of the remaining 17 items after the confirmatory factor analysis. Also, tolerance and VIF values are calculated. The VIF values are less than 3 (Kock, 2015).

Table 2. Mean, Standard Deviation, Normality

\begin{tabular}{|c|c|c|c|c|c|c|}
\hline Construct and Indicators & Mean & SD & Skewness & Kurtosis & Tolerance & VIF \\
\hline$S V$ & & & & & .917 & 1.090 \\
\hline I feel alive and vital. & 3.87 & 1.0 & -1.01 & .58 & & \\
\hline I don't feel very energetic. & 3.91 & 1.0 & -.81 & .04 & & \\
\hline I have energy and spirit. & 3.80 & .97 & -.90 & .64 & & \\
\hline $\begin{array}{l}\text { I look forward to each new } \\
\text { day. }\end{array}$ & 3.32 & 1.0 & -.38 & -.12 & & \\
\hline I feel energized & 3.69 & .92 & -.55 & .18 & & \\
\hline Learning & & & & & .561 & 1.782 \\
\hline $\begin{array}{l}\text { I expanded my } \\
\text { understanding of the } \\
\text { arboretum and the trees. }\end{array}$ & 4.29 & .77 & -1.26 & 2.66 & & \\
\hline $\begin{array}{l}\text { My curiosity about the } \\
\text { arboretum and trees was } \\
\text { enhanced. }\end{array}$ & 4.09 & .82 & -.76 & .49 & & \\
\hline Enjoyment & & & & & .562 & 1.780 \\
\hline I had fun. & 4.28 & .65 & -.54 & .05 & & \\
\hline $\begin{array}{l}\text { I derived a lot of pleasure } \\
\text { from the tour. }\end{array}$ & 4.26 & .71 & -.78 & .71 & & \\
\hline Escape & & & & & .613 & 1.630 \\
\hline $\begin{array}{l}\text { I felt like I was in another } \\
\text { world. }\end{array}$ & 4.00 & .93 & -.78 & .22 & & \\
\hline I got away from it all. & 3.94 & .98 &,- 62 & -.29 & & \\
\hline $\begin{array}{l}\text { I got so involved that I forgot } \\
\text { everything else. }\end{array}$ & 3.52 & 1.00 & -.37 & -.27 & & \\
\hline$A S$ & & & & & .645 & 1.551 \\
\hline $\begin{array}{l}\text { I feel more connected to the } \\
\text { park. }\end{array}$ & 3.83 & .89 & -.41 & -.24 & & \\
\hline $\begin{array}{l}\text { I have more respect for the } \\
\text { work of the park employees. }\end{array}$ & 4.18 & .76 & -.81 & .77 & & \\
\hline $\begin{array}{l}\text { I feel more inclined to help } \\
\text { this park. } \\
B I\end{array}$ & 3.97 & .84 & -.71 & .61 & & \\
\hline $\begin{array}{l}\text { I feel more inclined to visit } \\
\text { this park on a regular basis. }\end{array}$ & 4.07 & .86 & -.89 & .92 & & \\
\hline $\begin{array}{l}\text { I will more likely tell others } \\
\text { about this park. }\end{array}$ & 4.41 & .68 & -1.17 & 2.03 & & \\
\hline
\end{tabular}


Harman's (1976) single factor-test approach is utilized in this investigation to see if common method variance is a problem with this sample. If the interpretation coefficient of the first factor that is not rotated does not surpass $50 \%$ in exploratory factor analysis of all items, it is generally assumed that the common method variance is typically regarded to be within acceptable limits. The interpretation factor found is $29.7 \%$, which is significantly less than the standard of $50 \%$. Hence, it was expected that there would be no concerns with common method variance in this study.

\section{Confirmatory Factor Analysis (CFA)}

Under the recommended two-step approach to SEM (Anderson \& Gerbing, 1988), CFA was performed at first. Further, to ensure the suitability of the research instrument, reliability and construct validity scores were examined. Cronbach's alpha and Fornell's composite reliability (CR) scores were used to check the internal consistency for reliability (Fornell \& Larcker, 1981). Two items in the vitality scale were deleted because the standardized loadings were below the recommended cut-off level of 0.60 (Bagozzi \& Yi, 1988), and the remaining 17 items and constructs were reanalyzed. The results of CFA suggested that the model was a good fit except for the significant chi-square value $\left(x^{2}=220.17 ; \mathrm{df}=110 ; \mathrm{p}<0.001\right.$; $\mathrm{CMIN} / \mathrm{df}=2.000$ ), which could be influenced by sample size. The other indices were listed as GFI=0.94; $\mathrm{AGFI}=0.91$; $\mathrm{CFI}=0.96$; $\mathrm{TLI}=0.95$; $\mathrm{RMSEA}=$ 0.051 . Table 3 shows factor loadings, t-values, Cronbach's alpha, Fornell's CR scores, and average variance extracted (AVE) values. The results indicated adequate internal consistency and convergent validity except for the "learning" construct, which was barely below the specified cut-off points for AVE and CR. As it is one of the fundamental elements of the second-order construct, the "learning" variable was not excluded from the analysis.

Table 3. Reliability and Convergent Validity

\begin{tabular}{lccccc}
\hline Construct and Items & $\begin{array}{l}\text { Factor } \\
\text { Loading }\end{array}$ & t-value & $\begin{array}{c}\text { Cronbach's } \\
\text { Alpha }\end{array}$ & CR & AVE \\
\hline First-order & & & & & \\
SV & & & .84 & .85 & .53 \\
I feel alive and vital. & .80 & $\lambda$ set to 1 & & & \\
I don't feel very energetic. & .77 & 15.1 & & & \\
I have energy and spirit. & .78 & 15.4 & & & \\
I look forward to each new day. & .56 & 10.8 & & & \\
I feel energized & .70 & 13.7 & & & \\
\hline
\end{tabular}




\begin{tabular}{|c|c|c|c|c|c|}
\hline Learning & & & .65 & .66 & .49 \\
\hline $\begin{array}{l}\text { I expanded my understanding of } \\
\text { the arboretum and the trees. }\end{array}$ & .69 & 9.9 & & & \\
\hline $\begin{array}{l}\text { My curiosity about the arboretum } \\
\text { and trees was enhanced. }\end{array}$ & .71 & $\lambda$ set to 1 & & & \\
\hline Enjoyment & & & .70 & .70 & .54 \\
\hline I had fun. & .76 & 11.4 & & & \\
\hline $\begin{array}{l}\text { I derived a lot of pleasure from } \\
\text { the tour. }\end{array}$ & .71 & $\lambda$ set to 1 & & & \\
\hline Escape & & & .80 & .80 & .58 \\
\hline I felt like I was in another world. & .78 & 13.0 & & & \\
\hline I got away from it all. & .79 & 13.2 & & & \\
\hline $\begin{array}{l}\text { I got so involved that I forgot } \\
\text { everything else. }\end{array}$ & .71 & $\lambda$ set to 1 & & & \\
\hline$A S$ & & & .79 & .79 & .56 \\
\hline I feel more connected to the park. & .74 & $\lambda$ set to 1 & & & \\
\hline $\begin{array}{l}\text { I have more respect for the work } \\
\text { of the park's administration. }\end{array}$ & .72 & 12.8 & & & \\
\hline $\begin{array}{l}\text { I feel more inclined to help this } \\
\text { park. }\end{array}$ & .78 & 13.7 & & & \\
\hline$B I$ & & & .72 & .73 & .58 \\
\hline $\begin{array}{l}\text { I feel more inclined to visit this } \\
\text { park regularly. }\end{array}$ & .71 & $\lambda$ set to 1 & & & \\
\hline $\begin{array}{l}\text { I will more likely tell others about } \\
\text { this park. }\end{array}$ & .81 & 10.8 & & & \\
\hline \multicolumn{6}{|l|}{ Second-order } \\
\hline$E Q$ & & & .83 & .88 & .70 \\
\hline Learning & .84 & $\lambda$ set to 1 & & & \\
\hline Enjoyment & .87 & 9.0 & & & \\
\hline Escape & .80 & 8.9 & & & \\
\hline
\end{tabular}

Discriminant validity (DV) was evaluated by comparing the square root of AVE and inter-construct correlations. Table 4 presents the correlation coefficients and the square root of AVE values. Although the square root of AS's AVE value was slightly above one of the inter-construct correlations, we assumed that DV was achieved.

Table 4. DV Scores

\begin{tabular}{lcccc}
\hline & $\mathbf{1}$ & $\mathbf{2}$ & $\mathbf{3}$ & $\mathbf{4}$ \\
\hline$B I$ & $.76^{\mathrm{a}}$ & & & \\
$S V$ & .24 & .73 & & \\
$A S$ & .72 & .23 & .75 & .83 \\
$E Q$ & .66 & .34 & .78 & \\
\hline $\mathrm{a}=$ Diagonal elements are the square root of AVE. & & \\
$\mathrm{p}<0.001$ & & & \\
\hline
\end{tabular}




\section{Structural model (SM) and hypothesis testing}

Next, the SM was tested using standardized path coefficients, t-statistics, and $\mathrm{R}^{2}$ estimates. The fit indexes for the $\mathrm{SM}\left(\mathrm{x}^{2}=225.22 ; \mathrm{df}=112 ; \mathrm{p}<0.001\right.$; $\mathrm{GFI}=0.93 ; \mathrm{AGFI}=0.91 ; \mathrm{CFI}=0.95 ; \mathrm{TLI}=0.95 ; \mathrm{RMSEA}=0.051$ ) suggest a high model fit to the data. The parameter estimates of the model and $\mathrm{R}^{2}$ values are presented in Fig. 2 and the results of the three hypotheses are indicated in Table 5. The $\mathrm{R}^{2}$ of EQ, AS, and BI are 0.11, 0.63, and 0.56, respectively. All values are above the recommended value of 0.10 (Falk \& Miller, 1992).

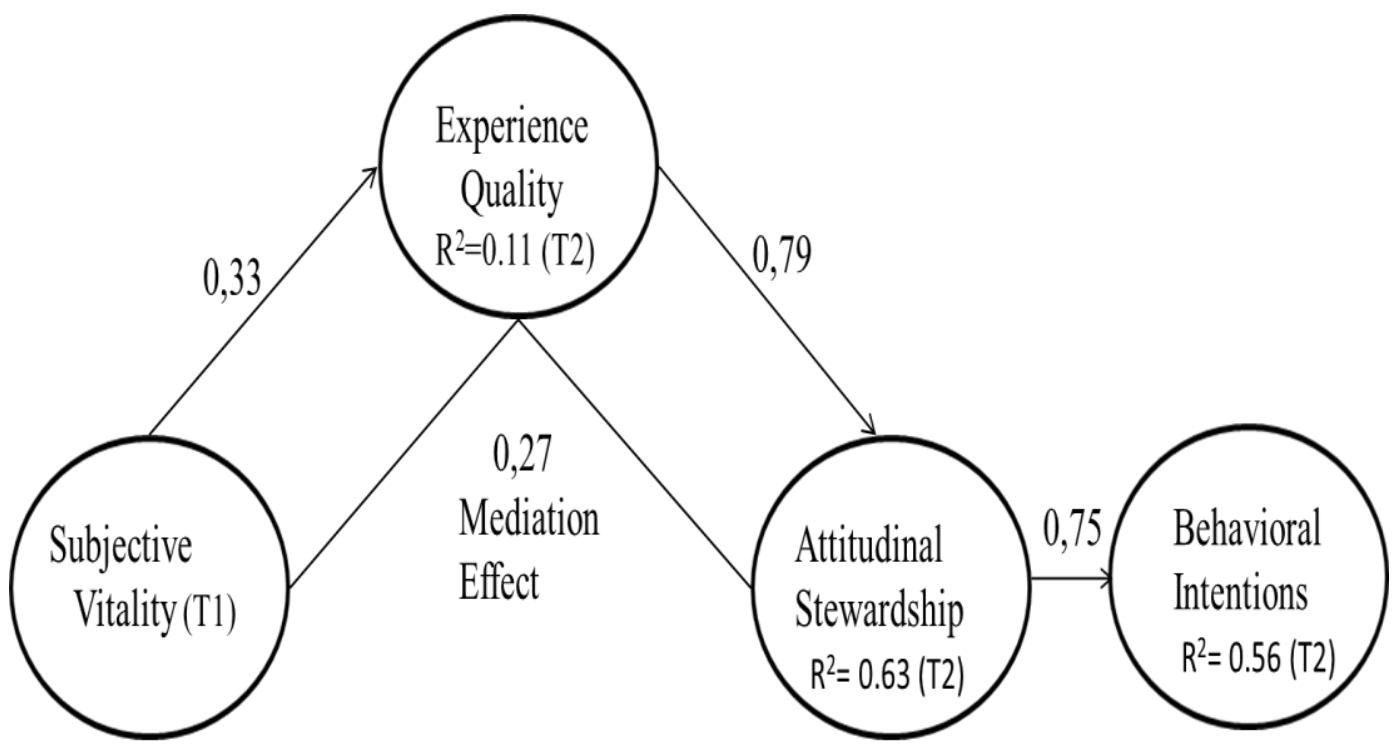

Figure 2. Estimated Results of the Model

All of the presented research hypotheses are supported. $\mathrm{H} 1$ predicts that SV level affects EQ. The analysis results support H1 because a positive and statistically significant relationship was found $(\beta=0.33, t=5.1, p<$ 0.001). H2 predicts that EQ level affects AS. A positive and statistically significant relationship was found $(\beta=0.79, \mathrm{t}=9.1, \mathrm{p}<0.001)$, hence the analysis results support $\mathrm{H} 2$. H3 predicts that AS level affects BI. The analysis results support $\mathrm{H} 3$ with a statistically significant relationship $(\beta=$ $0.75, \mathrm{t}=9.5, \mathrm{p}<0.001)$.

Table 5. Hypotheses Tests

\begin{tabular}{lccc}
\hline Hypothesis & Path Coefficient & t-value & Results \\
\hline H1 SV $\rightarrow$ EQ & .33 & $5.1^{\text {a }}$ & Supported \\
H2 EQ $\rightarrow$ AS & .79 & $9.1^{\text {a }}$ & Supported \\
H3 AS $\rightarrow$ BI & .75 & $9.5^{\mathrm{a}}$ & Supported \\
\hline${ }^{\mathrm{a} p}<0.001$ & & & \\
\hline
\end{tabular}




\section{The Mediating Role of Experience Quality}

The hypothesis that EQ would mediate the relationship between vitality and AS was tested. According to Zhao et al. (2010), when using SEM or regression to discover mediation, only the indirect effects should be significant to demonstrate the whole effect of mediation, however if both the direct and indirect regression coefficients are significant, partial mediations are supported. It is contained in Table 6 that EQ plays a full mediating role between vitality and AS. The direct effect of vitality on AS $(\beta=0.23, t=3.8, p<0.001)$ is no longer significant in the presence of the mediator variable.

Table 6. The Mediating Effect

\begin{tabular}{lllllll}
\hline Path & Effects & & $\begin{array}{l}\mathbf{p} \\
\text { value }\end{array}$ & \multicolumn{2}{l}{$\begin{array}{l}\text { Bias-corrected } \\
\text { Percentile 95\% CI }\end{array}$} & Mediation \\
\cline { 4 - 5 } & & & & Lower & Upper & \\
\hline H4 SV $\rightarrow$ EQ $\rightarrow$ AS & $\begin{array}{l}\text { Standardized } \\
\text { Direct Effects }\end{array}$ & -.02 & .700 & -.111 & .066 & Yes \\
& $\begin{array}{l}\text { Standardized } \\
\text { Indirect } \\
\text { Effects }\end{array}$ & .27 & .001 & .185 & .363 & \\
\hline
\end{tabular}

\section{DISCUSSION AND CONCLUSIONS}

\section{Theoretical Implications}

The level of energy is critical for better life quality. A person with high energy seems to have some advantages in life. For example, he can perform better at work and have a healthier life and higher life satisfaction. Similarly, a person who has high vitality while being engaged in tourism activities, which is considered as one of the biggest sources of entertainment in life, can undergoa better quality of experience. Despite its significant impact, the concept of SV seems to be neglected in the tourism and marketing literature (Altunel \& Koçak, 2017; Su et al., 2020). Therefore, the primary objective of this research study was to determine the effect of SV on EQ via CoR theory, the mediation role of EQ between SV and AS, and explore the interrelationship among SV, EQ, AS, and BI.

It would be incorrect to think that the determinative role played by the tourists' SV levels on their experiences is limited to only one type of tourism. However, this effect may be very limited in tourism or recreation types where a low level of physical energy and vitality is sufficient to complete the activity. For this reason, the research was carried out in the 
arboretum and outdoor recreational area, which necessitates a certain energy level for participation in activities, such as walking and planting. In previous studies, the effect of positive vitality on experience has not been investigated in this context. Besides, in two previous studies (Altunel \& Koçak, 2017; Su et al., 2020) that examined the impact of SV on EQ, the data were collected at a certain moment in time. However, in this study, the SV levels of the volunteers were measured before the audio tour in the arboretum, and thus the temporal precedence of causality was achieved.

The positive effect of SV on experiencing quality is the central finding of the study. This finding reveals that SV is a critical resource of a person and it reaffirms the results of previous studies (Altunel \& Koçak, 2017; Su et al., 2020). Moreover, the relationship discussed in the context of cultural tourism in the previous two studies also appears to be confirmed in the visit of the arboretum, which can be handled within the scope of outdoor recreation or garden tourism. Many psychological attributes are both stable and fluctuating over time, and existing research rarely employ theoretical models that account for both stability and change. Hence, SV can be examined in two different ways, traits and states; the first one refers to the enduring characteristics of individuals and the second to the temporary one. In contrast to other studies, the concept of SV in this study was approached as a trait. The trait-based approach of SV covers individual qualities that are temporarily stable and may have a consistent influence on individual experiences.

The study contributes to the existing literature in that it attempts to explain the effect of trait of SV on EQ with a theory. There is no theoretical explanation in previous studies examining this relationship. Su et al. (2020) claimed that their work adds to the theory of SV, but SV is a trait or state property rather than a theory. However, judging from the corrolaries of CoR theory, it can be claimed that people with less vitality have lower EQ, whereas people with higher vitality experience a higher quality of experience. In this way, the theoretical basis of the relationship can be demonstrated.

Additionally, the results demonstrate that the EQ plays a full mediation role in the impact of SV on AS. SV must rely on EQ to have an impact on AS. Although no scholar investigated this specific mediation relationship, this result is following Su et al.'s (2020) study, which discovered that AE partially mediates the relationship between SV and EQ.

Similarly, the significant and positive effect of EQ on the AS (Kang \& Gretzel, 2012), and that of the AS on BI, are in line with the literature 
(Dresner et al., 2015; Polonsky et al., 2012). A good experience will help the visitor feel more connected to the park, more willing to help, and more inclined to revisit and advocate.

\section{Managerial Implications}

In his dissertation on the use of gardens in England for tourism and recreation, Connell (2002) asked the garden owners about the reasons for opening up their gardens to the public. The two most important reasons were found to be charity fund-raising and covering gardening expenses. When garden owners were asked whether their basic motivations in this matter changed over time, they said it shifted towards financial reasons since it is difficult for a garden to survive without visitors. Indeed, private and public gardens, arboretums, and national parks require income from visitors and the work of volunteers to survive. The higher the satisfaction of the visitors regarding their experiences, the more willing they would be to revisit; some may even become volunteers. For this reason, the target group should be determined well concerning the services offered and the activities organized. An incorrectly determined target group will result in dissatisfaction, and this lack of planning may hamper the progress of a welldesigned event. As the SV level affects the quality of experience, vitality and energy should be used as a segmentation criterion (Plog, 1979). It would be wise for the parks to prefer people with higher levels of vitality because they have limited staff and budget, are selective in terms of event participation, and need volunteers to work. The parks with more facilities should differentiate the activities according to the vitality levels of the people and ensure that visitors with the targeted vitality level participate in the events.

One study to determine the visitor profile of the Atatürk arboretum found that the visitors mostly visited the arboretum to take a wedding photo or take a walk; they stated that they aimed to rest, feel refreshed, stay away from stressful environments, and spend time with their friends (Zeleke, 2018). These reasons are related to the escape and entertainment aspects of the EQ. However, the visitors mentioned a limited number of reasons related to the learning dimension. One reason might be that no interesting and informative activities were organized around the trees and other life-forms in the arboretum limiting the entertainment and stressrelief value. Visitors who do not know the stories of the trees within the arboretum do not participate in new planting activities; thus, they are not able to connect with nature and are not sensitized enough to protect it. This disassociation may result in more staff being employed to carry out these 
duties or risk the debilitation of the park due to a shortage of staff. Nevertheless, it seems reasonable to target different segments than wedding photography by organizing audio tours on the walking routes that introduce all wildlife with interesting stories and by organizing educational and entertaining activities with gamified applications. In this way, visitors with the preferred quality and quantity scores can be incentivized, and nature protection will be undertaken by conscious, nature-loving individuals.

\section{Limitations of the Study}

The psychological components that make up the SV concept consist of both permanent and state-specific emotional responses and, therefore, are treated with two different scales: SV trait (permanent) and SV state (statespecific) (Ryan \& Frederick, 1997). The state-related features of this concept can increase by being in nature (Ryan, et. al., 2010). However, this study only considered SV as a trait and, therefore, the state-effects of SV were not discussed as an alternative explanation for an increase in the EQ level. To consider the effects of SV as a state, future studies can include "being outdoor" as a control variable.

\section{REFERENCES}

Ajzen, I., \& Fishbein, M. (1980). Understanding attitudes and predicting social behavior. Englewood Cliffs, NJ: Prentice-Hall.

Allen, T. D., \& Kiburz, K. M. (2012). Trait mindfulness and work-family balance among working parents: The mediating effects of vitality and sleep quality. Journal of Vocational Behavior, 80(2), 372-379.

Altunel, M. C., Çakır, O., \& Akova, O. (2017). The Relationships Between Social Support by the Colleagues, Work-Holiday Interference, Recovery Experience and Holiday Satisfaction. In R. Efe, R. Penkova... \& J. G. Berdenov (Eds.), Developments in Social Sciences (pp. 595-612). Sofia: St. Kliment Ohridski University Press.

Altunel, M. C., \& Koçak, Ö. E. (2017). The roles of subjective vitality, involvement, experience quality, and satisfaction in tourists' behavioral intentions. European Journal of Tourism Research, 16, 233.

Anderson, J. C., \& Gerbing, D. W. (1988). Structural equation modeling in practice: A review and recommended two-step approach. Psychological Bulletin, 103(3), 411.

Cambridge Dictionary (n.d.). Arboretum. Retrieved January 20, 2021, from https:/dictionary.cambridge.org/dictionary/english/arboretum

Arkes, H. R., Herren, L. T., \& Isen, A. M. (1988). The role of potential loss in the influence of affect on risk-taking behavior. Organizational Behavior and Human Decision Processes, 42(2), 181-193.

Atwood, M. (2010). Oryx and Crake (Vol. 1). Toronto: Knopf Canada.

Bagozzi, R. P., \& Yi, Y. (1988). On the evaluation of structural equation models. Journal of the Academy of Marketing Science, 16(1), 74-94. 
Balaguer, I., Castillo, I., Cuevas, R., \& Atienza, F. (2018). The importance of coaches' autonomy support in the leisure experience and well-being of young footballers. Frontiers in Psychology, 9, 840.

BGCI, (2020). Garden Search Database. Retrieved December 23, 2021, from https://www.bgci.org/about/about-botanic-garden/.

Benfield, R. (2013). Garden Tourism. Wallingford: CABI.

Biddle, S. J., \& Mutrie, N. (2007). Psychology of physical activity: Determinants, well-being and interventions. Abingdon, UK: Routledge.

Binkhorst, E. (2007). Creativity in tourism experiences: The case of Sitges. In G. Richards \& J. Wilson (Eds.), Tourism, Creativity and Development (pp. 147-166). Abingdon: Routledge.

Brown, K. W., \& Ryan, R. M. (2004). Perils and promise in defining and measuring mindfulness: Observations from experience. Clinical Psychology: Science and Practice, 11(3), 242-248.

Čakovská, B. (2018). Garden tourism: Reasons for opening private gardens in the UK National Garden Scheme. Current Issues in Tourism, 21(12), 1344-1348.

Carmeli, A., Ben-Hador, B., Waldman, D. A., \& Rupp, D. E. (2009). How leaders cultivate social capital and nurture employee vigor: Implications for job performance. Journal of Applied Psychology, 94(6), 1553.

Chang, L. C., \& Kao, I. C. (2019). Enhancing social support and subjective vitality among older adults through leisure education. International Psychogeriatrics, 31(12), 18391840.

Chang, T. Y., \& Horng, S. C. (2010). Conceptualizing and measuring experience quality: The customer's perspective. The Service Industries Journal, 30(14), 2401-2419.

Chen, G., \& Sun, W. (2018). The role of botanical gardens in scientific research, conservation, and citizen science. Plant Divers. 40(4), 181-188.

Connell, J. (2002). A critical analysis of gardens as a resource for tourism and recreation in the UK. Unpublished doctoral dissertation, University of Plymouth, United Kingdom.

Connell, J. (2004). The purest of human pleasures: The characteristics and motivations of garden visitors in Great Britain. Tourism Management, 25(2), 229-247.

Csikszentmihalyi, M. (1990). Flow: The psychology of optimal experience. New York: Harper \& Row.

Çelik, E. (2017). Examining the mediating effect of subjective vitality in the proactive personality and life satisfaction relationship. International Journal of Happiness and Development, 3(4), 289-302.

Davis, F. D., Bagozzi, R. P., \& Warshaw, P. R. (1992). Extrinsic and intrinsic motivation to use computers in the workplace 1. Journal of Applied Social Psychology, 22(14), 11111132.

Deen, L., Dich, N., Head, J., \& Clark, A. J. (2020). Changes in emotional vitality as a predictor of levels and change in allostatic load: Longitudinal results From the Whitehall II cohort study. Psychosomatic Medicine, 82(4), 432-439.

DeVries, M. W., \& Sameroff, A. J. (1984). Culture and temperament: influences on infant temperament in three East African societies. American Journal of Orthopsychiatry, 54(1), 83.

Dopko, R. L., Capaldi, C. A., \& Zelenski, J. M. (2019). The psychological and social benefits of a nature experience for children: A preliminary investigation. Journal of Environmental Psychology, 63, 134-138. 
Dresner, M., Handelman, C., Braun, S., \& Rollwagen-Bollens, G. (2015). Environmental identity, pro-environmental behaviors, and civic engagement of volunteer stewards in Portland area parks. Environmental Education Research, 21(7), 991-1010.

Dubreuil, P., Forest, J., \& Courcy, F. (2014). From strengths use to work performance: The role of harmonious passion, subjective vitality, and concentration. The Journal of Positive Psychology, 9(4), 335-349.

Erdoğan, B., Bauer, T. N., Truxillo, D. M., \& Mansfield, L. R. (2012). Whistle while you work: A review of the life satisfaction literature. Journal of management, 38(4), 10381083.

Falk, R. F., \& Miller, N. B. (1992). A primer for soft modeling. Akron, OH: University of Akron Press.

Falkner, R., \& Buzan, B. (2019). The emergence of environmental stewardship as a primary institution of global international society. European Journal of International Relations, 25(1), 131-155.

Ferreira, S. (2012). Moulding urban children towards environmental stewardship: The Table Mountain National Park experience. Environmental Education Research, 18(2), 251-270.

Fick, G. R., \& Ritchie, J. R. B. (1991). Measuring service quality in the travel and tourism industry. Journal of Travel Research, 30(2), 2-9.

Fini, A. A. S., Kavousian, J., Beigy, A., \& Emami, M. (2010). Subjective vitality and its anticipating variables on students. Procedia-Social and Behavioral Sciences, 5, 150156.

Fornell, C., \& Larcker, D. F. (1981). Evaluating structural equation models with unobservable variables and measurement error. Journal of Marketing Research, 18(1), 39-50.

Freud, S. (1962). The Ego and the d. New York: Norton.

Atatürk Arberotum (n.d.). Genel Bilgiler. Retrieved January 15, 2021 from https://ataturkarboretumu.ogm.gov.tr/tr/sayfa/genel-bilgiler

Gentile, C., Spiller, N., \& Noci, G. (2007). How to sustain the customer experience: An overview of experience components that co-create value with the customer. European Management Journal, 25(5), 395-410.

Department of Conservation of the New Zealand Government (n.d.). Get Involved. Retrieved February 08, 2021 from https://www.doc.govt.nz/get-involved/

Gonda, X., Vázquez, G. H., Akiskal, K. K., \& Akiskal, H. S. (2011). From putative genes to temperament and culture: cultural characteristics of the distribution of dominant affective temperaments in national studies. Journal of Affective Disorders, 131(1-3), 45-51.

Hair, J. F.; Black, W. C., Babin, J. B., Anderson, R. E., \& Tatham, R. L. (2006). Multivariate data analysis. Upper Saddle River, NJ: Pearson Education Inc.

Hair, J. F., Anderson, R. E., Babin, B. J., \& Black, W. C. (2010). Multivariate data analysis: A global perspective (Vol. 7). Upper Saddle River: Prentice Hall.

Halliwell, P. M. (2019). National Park citizen science participation: exploring place attachment and stewardship. Unpublished doctoral dissertation, University of Plymouth, United Kingdom.

Hancock, P. (2007). Assessing an Individual's Sense of Stewardship and the Successful Characteristics of Volunteer Stewardship Groups. Unpublished master of science thesis, Northern Arizona University, USA.

Harman, H. H. (1976). Modern factor analysis. Chicago: University of Chicago Press. 
Headey, B., \& Wearing, A. (1989). Personality, life events, and subjective well-being: toward a dynamic equilibrium model. Journal of Personality and Social Psychology, 57(4), 731.

Hertzog, C., Kramer, A. F., Wilson, R. S., \& Lindenberger, U. (2008). Enrichment effects on adult cognitive development: can the functional capacity of older adults be preserved and enhanced? Psychological science in the public interest, 9(1), 1-65.

Hobfoll, S. E. (1998). Stress, Culture, and Community: The Psychology and Physiology of Stress. New York: Plenum Press.

Hobfoll, S. E. (2011). Conservation of resource caravans and engaged settings. Journal of Occupational and Organizational Psychology, 84(1), 116-122.

Holmgrenn, L., Tirone, V., Gerhart, J., Hobfoll, S. E., Cooper, C. L., \& Quick, J. C. (2017). Conservation of resources theory: resource caravans and passageways in health contexts. In C. L. Cooper \& J. C. Quick (Eds.), The handbook of stress and health: A guide to research and practice (pp. 443-457). New York: John Wiley \& Sons Ltd..

Hoover, K. S. (2021). Children in nature: exploring the relationship between childhood outdoor experience and environmental stewardship. Environmental Education Research, 27(6), 894-910.

Jou, T. H. (1981). The Tao of Tai-Chi Chuan. Piscataway. NJ: Tai Chi Foundation.

$\mathrm{Ju}, \mathrm{H}$. (2017). The relationship between physical activity, meaning in life, and subjective vitality in community-dwelling older adults. Archives of Gerontology and Geriatrics, 73, 120-124.

Kang, M., \& Gretzel, U. (2012). Effects of podcast tours on tourist experiences in a national park. Tourism Management, 33(2), 440-455.

Kao, Y. F., Huang, L. S., \& Wu, C. H. (2008). Effects of theatrical elements on experiential quality and loyalty intentions for theme parks. Asia Pacific Journal of Tourism Research, 13(2), 163-174.

Kark, R., \& Carmeli, A. (2009). Alive and creating: The mediating role of vitality and aliveness in the relationship between psychological safety and creative work involvement. The International Journal of Industrial, Occupational and Organizational Psychology and Behavior, 30(6), 785-804.

Kas, M. J. H., De Mooij-van Malsen, J. G., De Krom, M., Van Gassen, K. L. I., Van Lith, H. A., Olivier, B., ... \& Holstege, F. C. P. (2009). High-resolution genetic mapping of mammalian motor activity levels in mice. Genes, Brain and Behavior, 8(1), 13-22.

Kheiraoui, F., Gualano, M. R., Mannocci, A., Boccia, A., \& La Torre, G. (2012). Quality of life among healthcare workers: A multicentre cross-sectional study in Italy. Public Health, 126(7), 624-629.

Ki, J. (2016). A Study of Korea Garden Industry's Profile and Development Direction. Journal of Korean Society for People, Plants and Environment, 19(1), 55-61.

Kobayashi, S., Terao, T., Shirahama, M., Hatano, K., Hirakawa, H., Kohno, K., ... \& Ishii, N. (2019). Relationship between hyperthymic temperament, self-directedness, and self-transcendence in medical students and staff members. Psychiatry and Clinical Neurosciences, 73(5), 277-283.

Kock, N. (2015). Common method bias in PLS SEM: A full collinearity assessment approach. International Journal of e-Collaboration, 11(4), 1-10.

Leiserowitz, A. A., Kates, R. W., \& Parris, T. M. (2006). Sustainability values, attitudes, and behaviors: A review of multinational and global trends. Annual Review of Environment and Resources, 31(1), 413-444.

Lipovská, B. (2013). The fruit of garden tourism may fall over the wall: Small private gardens and tourism. Tourism Management Perspectives, 6, 114-121. 
Lopez, C. W. (2020). Community geography as a model for improving efforts of environmental stewardship. Geography Compass, 14(4), e12485.

Lucas, A. G., Chang, E. C., Morris, L. E., Angoff, H. D., Chang, O. D., Duong, A. H., ... \& Hirsch, J. K. (2019). Relationship between hope and quality of life in primary care patients: vitality as a mechanism. Social Work, 64(3), 233-241.

Martin-Cuellar, A., Lardier Jr, D. T., \& Atencio, D. J. (2019). Therapist mindfulness and subjective vitality: The role of psychological wellbeing and compassion satisfaction. Journal of Mental Health, 30(1), 1-8.

Martin-Ruiz, D., Castellanos-Verdugo, M., \& de los Ángeles Oviedo-García, M. (2010). A visitors' evaluation index for a visit to an archaeological site. Tourism Management, 31(5), 590-596.

McNair, D., Lorr, M., \& Doppleman, L. (1971). Profile of mood states manual. San Diego: Educational and Industrial Testing Service.

Miller-Rushing, A., Primack, R., \& Bonney, R. (2012). The history of public participation in ecological research. Frontiers in Ecology and the Environment, 10(6), 285-290.

Mounce, R., Smith, P., Brockington, S., (2017). Ex situ conservation of plant diversity in the world's botanic gardens. Nat. Plants, 3, 795-802.

Nawijn, J., \& Veenhoven, R. (2011). The effect of leisure activities on life satisfaction: The importance of holiday trips. In I. Brdar (Ed.), The Human Pursuit of Well-Being (pp. 39-53). Amsterdam: Springer Netherlands.

Norman, L. (1999). Community empowerment approaches to environmental stewardship. Master's thesis, The University of Guelph, Canada.

Ok, K. \& Koç, M. (2019). Doğal değerlerin yönetimi ve sosyal pazarlama anlayışı: Atatürk Arboretumu örneği. Turkish Journal of Forestry, 20(4), 373-380.

Oreg, S., \& Katz-Gerro, T. (2006). Predicting pro-environmental behavior cross-nationally: Values, the theory of planned behavior, and value-belief-norm theory. Environment and Behavior, 38(4), 462-483.

Otto, J. E., \& Ritchie, J. B. (1996). The service experience in tourism. Tourism Management, 17(3), 165-174.

Pearce, P. L. (2005). Tourist behaviour: Themes and conceptual schemes. Bristol: Channel View Publications.

Penninx, B. W., Guralnik, J. M., Bandeen-Roche, K., Kasper, J. D., Simonsick, E. M., Ferrucci, L., \& Fried, L. P. (2000). The protective effect of emotional vitality on adverse health outcomes in disabled older women. Journal of the American Geriatrics Society, 48(11), 1359-1366.

Petitmengin, C. (2006). Describing one's subjective experience in the second person: An interview method for the science of consciousness. Phenomenology and the Cognitive sciences, 5(3-4), 229-269.

Pine, B. J., \& Gilmore, J. H. (1998). Welcome to the experience economy. Harvard Business Review, 76, 97-105.

Plog, S. C. (1979). Where in the world are people going and why do they want to go there. Paper presented at the meeting of the Tiangus Touristico Annual Conference, Acapulco, Mexico.

Polk, D. E., Cohen, S., Doyle, W. J., Skoner, D. P., \& Kirschbaum, C. (2005). State and trait affect as predictors of salivary cortisol in healthy adults. Psychoneuroendocrinology, 30(3), 261-272.

Polonsky, M. J., Vocino, A., Grau, S. L., Garma, R., \& Ferdous, A. S. (2012). The impact of general and carbon-related environmental knowledge on attitudes and behaviour of US consumers. Journal of Marketing Management, 28(3-4), 238-263. 
Porath, C., Spreitzer, G., Gibson, C., \& Garnett, F. G. (2012). Thriving at work: Toward its measurement, construct validation, and theoretical refinement. Journal of Organizational Behavior, 33(2), 250-275.

Qiu, X., Martin, G. B., \& Blache, D. (2017). Gene polymorphisms associated with temperament. Journal of Neurogenetics, 31(1-2), 1-16.

Ryan, R. M., \& Bernstein, J. (2004). Vitality/Zest/Enthusiasm/Vigor/Energy. In C. Petersen \& M. E. P. Seligman (Eds.), Character Strengths and Virtues: A Handbook and Classification (pp. 273-289). New York, NY: Oxford University Press.

Ryan, R. M., \& Frederick, C. (1997). On energy, personality, and health: Subjective vitality as a dynamic reflection of well-being. Journal of Personality, 65(3), 529-565.

Ryan, R. M., Weinstein, N., Bernstein, J., Brown, K. W., Mistretta, L., \& Gagne, M. (2010). Vitalizing effects of being outdoors and in nature. Journal of Environmental Psychology, 30(2), 159-168.

Sayılan, H. (2008). Endemik Bir Bitki Türü Olan Muş Lalesi'nin (Tulipa Sintenisii Baker) Botanik Turizmi (Bitki Gözlemciliği) Amaçlı Değerlendirilmesi. Paper presented at the meeting of the Ulusal Coğrafya Sempozyumu, Ankara, Turkey.

Salama-Younes, M., \& Hashim, M. (2018). Passion, vitality and life satisfaction for physically active old adults. The Journal of Positive Psychology, 13(3), 309-319.

Shirom, A. (2007). Explaining vigor: On the antecedents and consequences of vigor as a positive affect at work. In C. L. Cooper \& D. Nelson (Eds.), Organizational behavior: Accentuating the positive at work (pp. 86-100). Thousand Oaks, CA: Sage Publications.

Stern, M. J., Powell, R. B., \& Ardoin, N. M. (2008). What difference does it make? Assessing outcomes from participation in a residential environmental education program. The Journal of Environmental Education, 39(4), 31-43.

$\mathrm{Su}, \mathrm{X} ., \mathrm{Li}, \mathrm{X}$. , Chen, W., \& Zeng, T. (2020). Subjective vitality, authenticity experience, and intangible cultural heritage tourism: an empirical study of the puppet show. Journal of Travel \& Tourism Marketing, 37(2), 258-271.

Suhartanto, D., Brien, A., Primiana, I., Wibisono, N., \& Triyuni, N. N. (2020). Tourist loyalty in creative tourism: the role of experience quality, value, satisfaction, and motivation. Current Issues in Tourism, 23(7), 867-879.

Stewart, E. J., Hayward, B. M., Devlin, P. J., \& Kirby, V. G. (1998). The "place" of interpretation: A new approach to the evaluation of interpretation. Tourism management, 19(3), 257-266.

Swencionis, C., Wylie-Rosett, J., Lent, M. R., Ginsberg, M., Cimino, C., Wassertheil-Smoller, S., ... \& Segal-Isaacson, C. J. (2013). Weight change, psychological well-being, and vitality in adults participating in a cognitive-behavioral weight loss program. Health Psychology, 32(4), 439.

Thapa, B. (2010). The mediation effect of outdoor recreation participation on environmental attitude-behavior correspondence. The Journal of Environmental Education, 41(3), 133-150.

Thayer, R. E. (1987). Energy, tiredness, and tension effects as a function of a sugar snack vs. moderate exercise. Journal of Personality and Social Psychology, 52, 119-125.

TRT Belgesel - Turkish Radio Television Documentary (2015, October, 30). Ve Sonra - 6. Bölüm Boğaz'ın Boğası (And then- 6. Episode The Bull of Bosphorus) [Video]. Youtube. https://www.youtube.com/watch?v=lrrgLJPY_S4

Tsoi, S. L. T. A., de Boer, A., Croiset, G., Koster, A. S., van der Burgt, S., \& Kusurkar, R. A. (2018). How basic psychological needs and motivation affect vitality and lifelong 
learning adaptability of pharmacists: A structural equation model. Advances in Health Sciences Education, 23(3), 549-566.

Vargo, S. L., \& Lusch, R. F. (2004). Evolving to a new dominant logic for marketing. Journal of Marketing, 68(1), 1-17.

Wolf, I. D., Stricker, H. K., \& Hagenloh, G. (2015). Outcome-focused national park experience management: Transforming participants, promoting social well-being, and fostering place attachment. Journal of Sustainable Tourism, 23(3), 358-381.

Zeleke, A.N. (2018). İstanbul Atatürk Arboretumunun ziyaretçi profilinin pazar bölümlendirmesi. Unpublished master of science thesis, İstanbul University, İstanbul.

Zhao, X., Lynch Jr, J. G., \& Chen, Q. (2010). Reconsidering Baron and Kenny: Myths and truths about mediation analysis. Journal of Consumer Research, 37(2), 197-206. 